\title{
Awards that Celebrate Diversity in Children's Literature
}

\author{
COMPILED BY LAURA SCHULTE-COOPER
}

$\mathrm{S}$ o, you have just read "Day of Diversity: Extending the Dialogue, Encouraging the Action" (page 23) and you are eager to buy and promote diverse books, and read and support award-winning books given by diverse groups. But, where do you start? Right here! Below we've listed a sampling of book awards and recommended reading lists that highlight high-quality literature for young people about diverse peoples and triumphs of the human spirit.

The focus, given below for each award, was taken directly from descriptions at the award websites. Please visit individual sites for more information about the awards.

Jane Addams Children's Book Awards

Jane Addams Peace Association

http://bit.ly/cal-addams

First awarded: 1953

Focus: books that effectively promote the cause of peace,

social justice, world community, and equality.

American Indian Youth Literature Awards

American Indian Library Association

http://bit.ly/cal-aiyla

First awarded: 2006

Focus: writing and illustrations by and about American Indians.

\section{Américas Award}

Consortium of Latin American Studies Programs

http://bit.ly/cal-aba

First awarded: 1993

Focus: books that authentically and engagingly portray Latin

America, the Caribbean, or Latinos in the U.S.

\section{Arab American Book Award}

Arab American National Museum

http://bit.ly/cal-aaba

First awarded: 2007

Focus: books written by and about Arab Americans.

Asian/Pacific American Award for Literature

Asian/Pacific American Librarians Association

http://bit.ly/cal-apaal

First awarded: 2003

Focus: books about Asian/Pacific Americans and their heritage.
Mildred L. Batchelder Award

ALSC

http://bit.ly/cal-mlba

First awarded: 1968

Focus: books originally published in a language other than

English in a country other than the U.S., and subsequently

translated into English for publication in the U.S.

Pura Belpré Awards

ALSC

http://bit.ly/cal-pba

First awarded: 1996

Focus: books that best portray, affirm, and celebrate the Latino cultural experience.

\section{Amelia Bloomer Book List \\ ALA \\ http://bit.ly/cal-abbl \\ First released: 2002 \\ Focus: books with significant feminist content.}

\section{The Christopher Awards}

The Christophers

http://bit.ly/cal-ca

First awarded: 1949

Focus: media that affirm the highest values of the human spirit. 

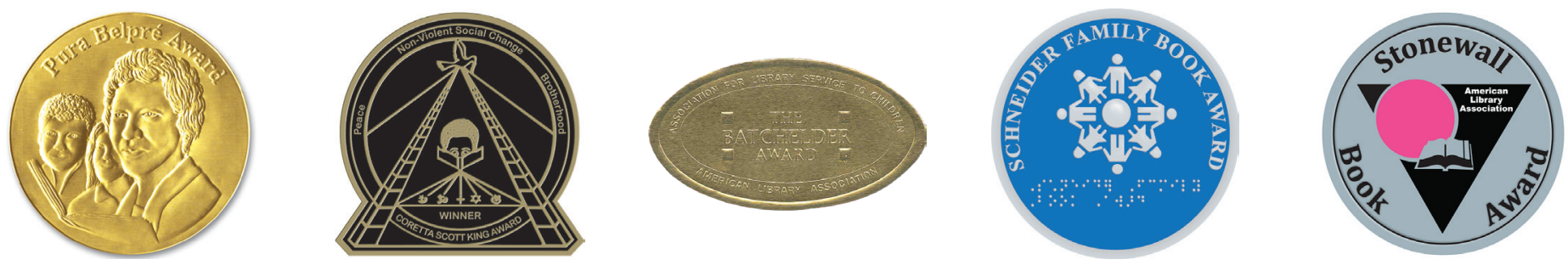

Dolly Gray Children's Literature Award

Council for Exceptional Children

http://bit.ly/cal-dga

First awarded: 2000

Focus: books that appropriately portray individuals with developmental disabilities.

\section{Ezra Jack Keats Book Award}

Ezra Jack Keats Foundation

http://bit.ly/cal-ejkba

First awarded: 1985

Focus: books that portray universal qualities of childhood, strong and supportive family, and multiculturalism.

\section{Coretta Scott King Book Awards}

ALA

http://bit.ly/cal-cska

First awarded: 1970

Focus: books that demonstrate an appreciation of African

American culture and universal human values.

Walter Dean Myers Award

We Need Diverse Books

http://bit.ly/cal-wdma

First awarded: February 2016

Focus: books that best exemplify Myers's commitment to providing children with powerful mirrors and windows.

\section{National Jewish Book Award}

Jewish Book Council

http://bit.ly/cal-njba

First awarded: children's literature, 1952; picture book, 1983

Focus: books of Jewish interest.

\section{Notable Books for a Global Society}

International Reading Association

http://bit.ly/cal-nbgs

First awarded: 1996

Focus: books that enhance understanding of individuals and cultures throughout the world.

\section{Once Upon a World Children's Book Award}

Museum of Tolerance

http://bit.ly/cal-ouw

First awarded: 1996

Focus: books that deal with issues of tolerance, diversity, and social justice.
Rainbow Book List

ALA

http://bit.ly/cal-rbl

First released: 2008

Focus: books with significant and authentic GLBTQ content.

Tomas Rivera Mexican American Children's Book Award Texas State University

http://bit.ly/cal-trba

First awarded: 1996

Focus: literature that depicts the Mexican American experience.

Schneider Family Book Award

ALA

http://bit.ly/cal-sfba

First awarded: 2004

Focus: books that embody an artistic expression of the disability experience.

Skipping Stones Honor Awards

Skipping Stones Magazine

http://bit.ly/cal-ssha

First released: 1994

Focus: multicultural and nature books.

\section{Stonewall Book Awards}

ALA

http://bit.ly/cal-sba

First awarded: 1971

Focus: books relating to the GLBT experience.

Sydney Taylor Book Award

Association of Jewish Libraries

http://bit.ly/cal-stba

First awarded: 1968

Focus: books that authentically portray the Jewish experience.

Carter G. Woodson Book Awards

National Council for the Social Studies

http://bit.ly/cal-cwba

First awarded: 1974

Focus: social studies-related books that depict ethnicity and race relations sensitively and accurately. 